\title{
MENCETAK PENDIDIK BERKUALITAS DALAM MENCEGAH RADIKALISME DAN KENAKALAN REMAJA MELALUI PENDEKATAN QOLB, NAFS DAN AQL
}

\begin{abstract}
Oleh:

Mohamad Aso Samsudin ${ }^{1}$ \&

Hasanah $^{2}$

Email:

1 moh.asosamsudin@gmail.com

2hasanahthahir2@gmail.com

Universitas Ibrahimy,

Situbondo

As buman live in the world, certainly will not become out from problem live that keep coming back. Therefore, education comes as a one of media to solv life problems experienced by each individual through the empowering of cognitive, affective and psychomotor potentials. However, in its development, the path of education is not always excellent. The various problems regularly occur in the world of education, especially correlated with students' immoral behavior. The role of the teacher as a key subject who has a more dominant portion of time to communicate with students is super vital in its existence to solve the problem of behavior deviation. Therefore, high quality of educators is needed. Educators, who are not only competent in utilizing cognitive potential but also proficient in preparing students with the noble character through deep understanding of the nafs, qolb and aql.
\end{abstract}

Keywords: Role of Teacher, Immoral Character, Nafs, Qolb, Aql

\section{PENDAHULUAN}

Peserta didik di Indonesia dapat kita ketahui bersama semakin meningkat jumlah populasinya. Hal tersebut dapat dilatar belakangi dengan adanya apresiasi yang tinggi dari seluruh elemen masyarakat tentang hadirnya pendidikan di tengah permasalahan hidup yang begitu kompleks. Memang sejatinya sebuah problematika kehidupan akan selalu menghantui siapapun yang telah menghuni dunia yang penuh dengan ketidak pastian ini. Namun demikian, cara mengatasi permasalah hidup tersebut sangatlah bervariatif dan juga butuh kemampuan tertentu. Belenggu permasalahan hidup tidak selamanya menjadi penyakit akut yang melumpuhkan seluruh potensi manusia hingga berada pada suasana ketidak berdayaannya.

\footnotetext{
1 Khairuddin Habziz, Kaidah Ushul Fiqh, (Situbondo: Tanwirul Afkar, 2019), 82.
}

Melalui akal dan pikiran, manusia dapat lari dari kompleksitas problematika kehidupan tersebut. Mendayagunakan akal dan pikirannya kadangkala semua permasalahan hidup dapat diatasi dengan mudah. Sebab akal dan pikiran adalah suatu anugerah yang diberikan oleh Allah kepada manusia yang makhluk-makhluk lainnya tidak memperoleh hal yang sama. Maka dari itulah, akal dan pikiran sekaligus juga menjadi diferensiasi antara semua makhluk ciptaan-Nya. Sebagaimana kaidah yang sangat populer didengung-dengungkan, yakni Al-Insanu Hayawanun Natiq (manusia ialah makhluq yang berakal). ${ }^{1}$

Aktivitas penempaan akal dan pikiran biasanya terjadi dalam sebuah proses pendidikan. Sebab jika ditarik dari sebuah definisinya, pendidikan merupakan usaha untuk menyadarkan manusia baik dari segi akal dan pikirannya agar 
mampu memahami realitas dunia yang tengah dihadapinya. ${ }^{2}$ Sejatinya pendidikan memang merupakan suatu hal yang bertujuan untuk mempersiapkan individu yang mampu mengatasi berbagai kompleksitas permasalahan realitas dunia yang mengitarinya. Sehingga pada akhirnya dapat tercapai sebuah tujuan pendidikan yang diutarakan oleh Plato bahwa pendidikan untuk membahagiakan hidup pribadi yang mempelajarinya. ${ }^{3}$

Itu sebabnya, mengapa pendidikan menjadi sebuah "pasar pengetahuan" yang banyak diminati oleh seluruh lapisan masyarakat. Jika merujuk perkataan Ki Hajar Dewantara yang mengatakan bahwa tujuan pengajaran adalah membahagiakan kehidupan individu secara lahiriah sedangkan pendidikan bertujuan untuk membahagiakan kehidupan individu secara batiniyah, maka sudah barang tentu pendidikan merupakan suatu hal yang begitu mulia untuk berproses menjalaninya. ${ }^{4}$ Meskipun pada prinsipnya Ki Hajar Dewantara mendikotomikan dua elemen antara pendidikan dan pengajaran, namun esensinya tujuan pendidikan tetaplah bermuara pada sumber kebahagiaan hidup manusia baik itu sisi lahiriah maupun batiniah.

Lebih eksplisit, seorang profesor muslim Ilmu Pendidikan di Universitas Tunisia dengan berkbangsaan Arab (Irak) mendiskusikan bahwa peranan pendidikan dalam hidup manusia terdapat dua bagian yaitu peranan pendidikan dalam memerangi keterbelakangan dan peranan pendidikan dalam mengembangkan iman serta ilmu. Banyak kita ketahui negara-negara maju yang dapat diindikasikan dengan perkembangan teknologinya super cepat dan canggih serta perkembangan finansial yang melesat setiap saat, tidak lain dan tidak bukan akal kita harus mengamini bahwa masyarakat yang hidup dalam negara tersebut sangat memperioritaskan pendidikan dalam kehidupannya.

Apa yang dikatakan oleh Siti Murtiningsih dalam bukunya yang berjudul Pendidikan sebagai Alat Perlawanan tentu tidak bertolah belakang dengan hal-hal yang telah diurai di atas, menurutnya, "Karena pendidikan, masyarakat dari sebuah negara menjadi maju, sebaliknya negara yang maju dapat dilihat dari pendidikan

2 Amirullah Syarbini, Pendidikan Karakter Berbasis Keluarga: Studi Tentang Model Pendidikan Karakter dalam Keluarga Perspektif Islam (Yogyakarta: Ar-Ruzz Media, 2016), 13.

3 Jalaluddin dan Abdullah Idi, Filsafat Pendidikan: Manusia, Filsafat dan Pendidikan, (Depok: Raja Grafindo Persada, 2016), 74 . yang diterapkannya." Pernyataan ini sebenarnya merupakan sebuah ilham dari statement Paulo Freire bahwa, "Pendidikan harus menjadi arena pembebasan manusia yang mampu menghantarkannya bersikap kritis dan kreatif dalam mengubah diri dan dunianya."

Di sisi lain, kemajuan tidak selalu identik dengan perkembangan teknologi dan kemapanan ekonomi. Sebab yang demikian itu adalah wasilah memperoleh tujuan yang mulia. Akan tetapi yang dikatakan dari sebuah kemajuan ialah melampaui dari hal-hal sebatas teknologi dan ekonomi, melainkan esensi dari kemajuan adalah cara bagaimana merealisasikan nilai-nilai kemanusiaan. ${ }^{5}$ Faktanya terdapat beberapa negara yang maju dalam bidang ilmu pengetahuan dan teknologinya serta mapan dalam segi ekonomi, akan tetapi mengalami kebobrokan nilai sosial dan karakter. Justru sebaliknya, terdapat negara yang terbelakang dalam segi teknologi akan tetapi sangat baik dalam bidang sosial, mental dan keseniannya.

Tentu interpretasi makna keterbelakangan sangatlah komprehensif. Namun semua pasti sepakat bila keterbelakangan tidak selalu dikaitkan pada satu aspek keilmuan saja, aspek moral juga memiliki posisi yang tidak kalah urgen untuk diimplementasikan. Selaras dengan hal tersebut di atas, faktanya banyak ketimpangan moral justru kerap kali terjadi di lingkungan pendidikan atau berkaitan dengan subjek yang berproses dalam institusi pendidikan. Seperti kenakalan remaja, baik berupa tawuran atau penyimpangan terhadap norma-norma masyarakat. Sebut saja di akhir penghujung tahun 2020 lalu sebagaimana yang telah dilansir oleh Tribunnews.com bahwa puluhan pelajar di Jatinegara terlibat aksi tawuran yang berlangsung selama 4 hari dan sampai menewaskan salah seorang warga setempat (Kamis, 29/10/2020). Mirisnya, tawuran yang terjadi saat ini bukan hanya pada kalangan pria saja akan tetapi juga wanita. Tribun Timur memberitakan belasan siswi SMA di Bangsal Mojokerto terjadi tawuran antar geng yang menyebabkan video ini viral dan menuai banyak kecaman dari warga net atas perilaku siswi yang menyimpang tersebut.

\footnotetext{
4 Ki Hajar Dewantara, Bagian Pertama: Pendidikan, (Yogyakarta, Yayasan Persatuan Taman Siswa, 2011), 3. 5 Abd. Aziz, Filsafat Pendidikan Islam: Sebuah Gagasan Membangun Pendidikan Islam, (Yogyakarta: Teras, 2009), 25.
} 
Aspek lain yang juga menggoyahkan dunia pendidikan ialah aksi radikalisme. Sebagaimana hasil laporan penelitian yang telah dilakukan pada bulan Oktober 2010 sampai 2011 oleh Lembaga Kajian Islam dan Perdamaian terhadap pendidik PAI dan peserta didik (SMP-SMA) di Jabodetabek menghasilkan bahwa 49\% siswa mengamini terhadap aksi radikalisme atas nama agama. ${ }^{6}$ Sebagai satu hal yang di dalamnya berproses jutaan umat manusia, tentu pendidikan tidak akan lepas dari kompleksitas permasalahan hidup yang selalu mewarnai pernak-pernik kehidupan manusia itu sendiri.

Oleh karena itulah, perlu adanya usaha efektif untuk menyelesaikan berbagai persoalan dalam dunia pendidikan, lebih-lebih permasalahan kenakalan remaja dan radikalisme agama. Salah satu peran penting yang potensial dalam menangkal hal terebut ialah kiprah dari seorang pendidik. Sebab pendidik adalah aktor utama yang memiliki kuota komunikasi lebih kepada peserta didik. Muatan materi pembelajaran yang akan diserap oleh siswa juga perlu diperhatikan oleh guru, seperti materi yang berkenaan dengan aspek ruhaniah sehingga bisa menenteramkan hati, menyejukkan jiwa, dan akal pikiran yang sehat.

\section{PEMBAHASAN}

\section{Gerakan Radikalisme Agama dan Kenakalan Remaja}

Tidak dapat dipungkiri bahwa eksistensi negara Indonesia adalah sebuah negara yang di atasnya berdiri ribuah kaki dengan latar belakang suku, ras, bahasa, agama, dan budaya yang berbeda-beda. Di sini dapat dipahami bahwa Indonesia merupakan bangsa yang majemuk, di dalamnya terdapat banyak kultur yang tumbuh dan berkembang. Kerap kali Indonesia juga disebut sebagai negara multikultural. Hal tersebut dapat dibuktikan dari situs sosio-kultural dan letak geografisnya yang begitu luas dan beragam. Tercatat bahwa total seluruh pulau yang dimiliki Indonesia sekitar 17.504 pulau yang di antaranya kurang lebih 11 ribu pulau telah dihuni oleh 359 suku dengan keragaman bahasa mencapai 726 . Tidak hanya itu, pada saat KH. Abdurahman

6 Abu Rokhmad, "Radikalisme Islam dan Upaya Deradikalisasi Paham Radikal," Walisongo, Vol. 20, No. 1, (Mei: 2012), 81.

7 Andik Wahyun Muqoyyidin, "Membangun Kesadaran Inklusif-Multikultural untuk Deradikalisasi Pendidikan
Wahid berkuasa, agama yang sah dijalankan bagi pemeluknya di Bumi Pertiwi ini terdapat 6 agama. Pasca panambahan agama Konghucu secara legal dan sah di antara 5 agama sebelumnya yakni, Islam, Budha, Hindu, Kristen, Katolik. Akan tetapi, dalam 6 agama tersebut terdapat banyak aliran yang menghiasi di dalamnya dan beberapa bentuk organisasi sosial. ${ }^{7}$ Di samping itu bermunculan berbagai aliran kepercayaankepercayaan hidup yang tumbuh subur di wilayah teritorial Indonesia.

Sebagai bangsa yang berdaulat, legalitas hukum formal dan birokrasi kepemerintahan di Indonesia harus dijalankan sebagaimana mestinya serta wajib ditaati oleh seluruh elemen bangsa. Namun setelah runtuhnya kekuasaan orde baru, terjadi banyak konflik yang bertebaran di Indonesia. Khususnya adalah kian banyaknya aksi terorisme dan radikalisme Islam. Hal ini dibuktikan dengan adanya ledakan bom yang kurang lebih hanya dalam kurun waktu satu dekade. Sebut saja bom buku yang terjadi di masjid Mapolres Cirebon, bom buku yang diperuntukkan ke sejumlah tokoh-tokoh berpengaruh, bom bunuh diri yang terjadi di GBIS (Gereja Bethel Injil Sepenuh) Solo. Tidak hanya itu, hal yang paling mencengangkan juga adalag ledakan bom yang terjadi di Bali, yakni bom Bali 1, bom Bali 2, bom Hotel JW Marriot 1, bom Hotel JW Marriot 2, bom Hotel Ritz Carlton, sampai bom kepada Kedutaan Besar Australia. ${ }^{8}$

Merebahnya kasus terorisme yang terjadi, mengindikasikan pada satu terma bahwa masyarakat Indonesia belum sepenuhnya memahami arti keberagaman sosial dan rasa saling hormat-menghormati atau sikap toleransi. Di antara satu kalangan bisa jadi sangat menginginkan ketiadaan pluralitas yang dimiliki Indonesia menjadi sebuah bentuk ketunggalan belaka atau keseragaman (uniformity), yang mana tentu sangat bertolak belakang sekali dengan akar historis bangsa Indonesia dengan berbagai keragaman yang mengitarinya. Hal ini perlu mendapat perhatian yang khusus dari seluruh lapisan masyrakat, terlebih pemerintah, sebab bila dibiarkan liar begitu saja, maka yang akan terjadi tidak hanya ancaman terhadap keamanan rakyat,

Islam”, Jurnal Pendidikan Islam, Vol. 2, No. 1, (Juni: 2013), 134.

8 Sufyan Syafi'i, "Urgensitas Sanad sebagai Modal Sosial Pesantren dalam Deradikalisasi Islam", The International Journal of Pegon Islam Nusantara Civilixation, Vol. 3, No. 2, (Maret: 2020), 172. 
akan tetapi stabilitas pemerintahan. Jika aksi terorisme ini sudah mengenai jantung sebuah negara, yakni tatanan birokrasi yang sah, maka konflik akut akan terjadi secara permanen.

Membasmi gerakan radikal dan terorisme tidak semudah membalikkan telapak tangan atau bahkan mengucapkan bimsalabim abrakadabra. Karena hal ini bersangkutan pada ranah kognitif, yakni pemahaman. Karena bila diinterogasi motif melakukan aksi terorisme dan radikalisme tersebut, mayoritas dari meraka mengatakan bahwa itu semua dilakukan sebab berdasarkan perintah agama. Alih-alih mereka yang melalukan aksi radikal tersebut selalu mengklaim bahwa semua yang telah dilakukannya merupakan suatu hal yang benar dan terpuji. Namun dalam konsep bernegara yang berdaulat serta masyarakat yang telah damai, tentu hal demikian kurang tepat dilakukan.

Gerakan atau pikiran yang berusaha fokus mencapai intisari atau maksud sebenarnya merupakan sebuah definisi dari radikal. Hal ini dapat dilihat dari segi harfiahnya yang mana radikalisme bermakna akar dari sebuah bahasa Latin, Radix. Bila dirujuk dalam Kamus Besar Bahaasa Indonesia, kata radikal memiliki pengertian bahwa aliran yang menginginkan sebuah revolusi melalui aksi kekerasan atau drastis. ' Akan tetapi terdapat pengertian yang lebih universal atau hakiki dari sebuah kata radikal, yakni suau gagasan atau action yang bermaksud untuk merubah dan melenyapkan suatu tatanan birokrasi politik yang telah berdaulat dengan suatu sistem yang dikehendaki secara sepihak berdasarkan keinginannya.

Berdasar internal agama, gerakan radikalisme sebenarnya merupakan respon atas ketidak puasan dari penerapan nilai-nilai agama yang biasanya dilakukan dengan cara kekerasan oleh sebagian pihak. Nilai-nilai agama yang semestinya menurut pihak ini harus dilakukan secara benar dan lurus, namun tidak semuanya dilakukan dan terserap oleh beberapa orang. Akan tetapi diksi-diksi sebagaimana hal tersebut merupakan persepsi kelompok radikalisme yang masih belum tentu benar adanya. Sebab sejatinya, agama Islam diturunkan untuk memperbaiki akhlak para umat yang kala itu kacau-balau melalui dakwah mulia Nabi Muhammad SAW.

${ }^{9}$ Tim Pandom Media, Kamus Besar Bahasa Indonesiia: Edisi Baru, (Jakarta: Pandom Media Nusantara, 2014), 676.
Baginda Nabi dengan sabar menuntun para umatnya guna memiliki keperibadian dan akhlak yang indah. Seiring memperbaiki akhlak para sahabat yang masuk Islam kala itu, Baginda Nabi juga mengajar hukum-hukum syari'at yang tegas.

Memang sebagaimana yang telah kita ketahui bersama, kedudukan hukum syariat dalam Islam memanglah sangat tegas dan mengikat. Tidak ada kompromi yang dapat melemahkan kedudukan hukum Islam. Kelompok-kelompok radikalis ini ingin menegakkan hukum syariat yang tegas dengan cara keras. Tentu hal tersebut bertolak belakang dengan historisitas dakwah Nabi Muhammad SAW yang mana sangat mengedepankan akhlak. Terbukti, pertama kali beliau berdakwah adalah dengan cara menyempurnakan akhlak terlebih dahulu. Kemudian disusul dengan menegakkan hukumhukum syariat yang tegas apa adanya.

Kiranya pada era modern ini, sisi pengentasan kemiskinan dan kesejahteraan sosial sebagai wasilah menuju dunia ukhrawi tidak kalah pentingnya dengan menegakkan hukum syariat secara tegas tanpa kekerasan. Sebagaimana yang telah diurai di atas, bahwa salah satu upaya dalam mengentaskan kemiskinan ialah melalui pendidikan. Namun ironinya, pendidikan saat ini sudah banyak ormas-ormas Islam yang mendirikan. Tentu masing-masing ormas Islam yang mendirikan lembaga pendidikan (TK/SD/SMP/SMA) mempunyai ciri khas tersendiri dalam sistem pengejarannya.

Pada biasanya, ciri-ciri yang melekat pada lembaga tersebut di antaranya: (1) Bercorak Islam Timur Tengah; (2) Sumber atau bahan ajar yang digunakan dalam memperoleh pemahaman tentang Islam; (3) Orientasi terhadap maknamakna baru seperti dawrah, halaqah, mabit, dan sebagainya. ${ }^{10}$ Tentu pengenalan istilah-istilah seperti dawrah, halaqah, mabit kepada peserta didik sejak saat dini sangatlah bagus. Karena hal tersebut merupakan sistem pembelajaran yang salah satunya juga diimplementasikan pada zaman Rasulullah SAW. Pengajaran tentang syariah dan akidah akan lebih natural disampaikan oleh guru. Namun pada sisi lain, pengajaran-pengajaran tersebut di atas cenderung berimplikasi pada lahirnya sikap intoleran peserta didik terhadap pihak lain. ${ }^{11}$

10 Abu Rokhmad, "Radikalisme Islam dan Upaya Deradikalisasi Paham Radikal", Walisongo, Vol. 20, No. 1, (Mei: 2012), 81

${ }^{11}$ Ibid. 
Dari sinilah seharusnya dunia pendidikan lebih berhati-hati terhadap pemahaman-pemahan radikal yang terus-menerus berupaya dilestarikan. Hal tersebut diperkuat oleh Azyumardi Azra, beliau mengatakan bahwa peserta didik di sekolah menjadi sasaran khusus rekrutmen kelompok radikalis dan teroris. Lebih lengkapnya, Guru Besar di UIN Syarif Hidayatullah ini mengungkapkan bahwa terdapat beberapa penelitian membuktikan adanya upaya rekrutmen ke institusi-institusi pendidikan, melalui upaya "cuci otak" terhadap peserta didik, yang selanjutnya diisi dengan ideologi radikal tertentu. $^{12}$

Permasalahan dalam dunia pendidikan tidak hanya sebatas radikalisme saja, melainkan kerusakan moral yang salah satunya disebabkan oleh kenakalan remaja. Terdapat beberapa klasifikasi fase remaja, yang pertama adalah remaja awal dalam kisaran 12-15 tahun, usia 1518 tahun adalah fase remaja pertengahan, sedangkan usia 18-21 tahun ialah fase remaja akhir. Secara umum siswa sekolah menengah atas dan sekolah menengah pertama di Indonesia berada pada kisaran umur 12-18 tahun. Pada fase remaja sering disebut sebagai storm dan stress karena pada fase ini seorang individu memiliki kompleksitas pengalaman hidup yang disebabkan oleh adanya perubahan fisik dan kelenjar. Tentu sebagai generasi emas sebuah bangsa, harapan besar terhadap remaja senantiasa bergulir yang membuatnya berada pada tekanan sehingga berimplikasi pada meningginya emosi.

Adanya rasa tertekan tersebut di atas, acapkali membuat para remaja tidak bisa keluar dari beberapa persoalan hidup yang mengitarinya. Sehingga banyak persepsi yang mengatakan bahwa usia remaja adalah usia yang bergelayut dengan masalah. Sehingga penanganan terhadap masalah yang dialami oleh remaja perlu mendapat perhatian ekstra. Hal ini disebabkan karena keangkuhan yang berlebih pada remaja, seolaholah mereka dapat menangani masalahnya dan bisa mencari solusinya sendiri tanpa bantuan keluarga, orang tua ataupun guru.

Kenakalan remaja dapat ditimbulkan dari banyak faktor, di antaranya adalah backgorund keluarga. Latar belakang keluarga seorang individu memang banyak berpengaruh terhadap

12 Andik Wahyun Muqoyyidin, "Membangun Kesadaran Inklusif-Multikultural untuk Deradikalisasi Pendidikan Islam”, Jurnal Pendidikan Islam, Vol. 2, No. 1, (Juni: 2013), 134. perilaku atau sikap seseorang. Penyebab utama terjadinya kenakalan remaja adalah keluarga yang berantakan, kemiskinan, dan sebagainya. Akan tetapi terdapat fakor atau keterampilan yang dapat membendung remaja untuk menjauh dari hal-hal yang bersifat kekerasan dan melebihi posisi keluarga bahkan ekonomi sekalipun. Keterampilan tersebut ialah kecerdasan emosional. Kecerdasan emosional memiliki arti sebagai kompetensi mengenali perasaan sendiri dan orang lain serta memiliki kemampuan memanage emosi tersebut dengan self motivation. ${ }^{13}$

Paham radikalisme dan kecerdasan emosional yang kedua-duanya memiliki kesamaan dalam segi kognisi sangat membutuhkan penempaan akal yang jernih. Artinya bahwa paham radikalisme dapat dibendung melalui pemahaman yang benar dan kecerdasan emosional dibentuk melalui pemahaman yang tulus serta luhur. Adapun habitat pembentukan pemahaman ialah di sekolah. Sehingga peran guru betul-betul diperhatikan guna membentuk kecerdasan emosional dan menangkal pemahaman radikal pada diri siswa. Para pendidik inilah yang pada akhirnya nanti akan menjadi mediator pertama untuk menerjemahkan nilainilai toleransi, pluralisme dan multikultural pada siswa, yang pada tahapan selanjutnya ikut berperan aktif dalam mentransformasikan kesadaran toleran secara lebih intens.

\section{Mutu Pendidik dan Metode Penanaman Karakter}

Dalam dunia pendidikan guru memiliki posisi sentral yang sangat strategis dalam menjalin komunikasi kepada siswa. Adakalanya guru juga berperan tak ubahnya sebagai "wasit" yang menghakimi dan menilai siswa. Namun di sisi lain, guru pun dituntut untuk menjadi partner bagi peserta didik. Mengingat adanya transformasi tugas seorang pendidik dari tradisionalis menuju profesionalis. Guru tradisionalis acap kali melakukan orientasi pembelajaran yang one ways communication, di mana posisi siswa sebagai objek kegiatan pembelajaran. Sedangkan posisi guru sebagai subjek pembelajaran atau yang lebih populer dengan sebutan teacher centered. posisi yang demikian menjadikan ilmu pengetahuan hanya berpusat pada guru. Peserta didik tak ubahnya

\footnotetext{
${ }^{13}$ Kartini Kartono, Kenakalan Remaja, (Jakarta: Raja Grafindo Persada, 2006), 53.
} 
sebagai pengepul pengetahuan yang harus mencatat segala informasi yang telah diberikan oleh guru kepadanya. ${ }^{14}$

Tentu aktivitas mengumpulkan informasi yang disampaikan oleh guru tanpa pemberian skill dasar berpikir kritis, secara temporal akan hilang dengan sendirinya. Peserta didik bukanlah "buku tabungan" yang diwajibkan menampung dan mencatat segala informasi di otaknya. Kemampuan yang dimiliki guru tradisional sering dilandasi dengan persepsi terhadap murid yang dijadikan seolah-olah "tabula rasa" (kertas kosong). Hal ini tentu beranggapan bahwa tidak ada potensi lahiriah yang melekat pada diri peserta didik menuju keperibadian yang kompetensial. Peserta didik dianggap sebagai manusia yang lahir tanpa potensi bawaan. Sehingga pendidikan lebih menjadi sarana mengisi pengetahuan dan keterampilan atas kekosongan potensi bawaan peserta didik yang sama sekali seperti kertas kosong tanpa coretan tinta. ${ }^{15}$ Berbagai koleksi data yang tersimpan dalam memori pikiran siswa tersebut dipaksa keluar secara periodik dalam bingkai Ujian Nasional.

Lalu, apa yang terjadi? Berdasarkan assessment result yang disampaikan oleh Trends in International Mathematics and Science Study mengatakan bahwa kompetensi berpikir murid di Indonesia menjadi rendah. Berkolerasi dengan hal terbut, yakni rendahnya kompentesi peserta didik pada matematika, sains, dan literasi juga tampak pada hasil penilaian yang dilakukan oleh Program for International Student Assessment (PISA) yang menilai tentang kemampuan siswa dalam memcahkan masalah yang dihadapi pada dunia nyata dengan menggunakan pisau pengetahuan yang telah dimilikinya. Maka dari itu, perlu adanya reorientasi tugas guru yang awalnya selalu berladaskan pada paradigma tradisionalis menuju profesionalis.

Guru profesional adalah seorang pendidik yang selalu memposisikan siswa sebagai subjek dari sebuah aktivitas pembelajaran. Siswa adalah makhluk yang memiliki segudang potensi bawaan yang tumbuh dan berkembang bersama lingkungan yang mengitarinya. Guru profesional akan menyediakan kesempatan dialogis bagi siswa dan guru ataupun antar sesama siswa. Sehingga model pendidikan yang menekankan pada posisi dua arah akan terwujud dengan sempurna oleh

\footnotetext{
14 William A. Smith, Conscientizacao: Tujuan Pendidikan Paulo Freire, (Yogyakarta: Pustaka Pelajar, 2008), 33.
}

upaya-upaya dari tangan guru profesional. Apa yang menjadi egosentrismenya sebagai makhluk yang serba tahu tentang segala hal dan banyak melakukan instruksi paternalistik, secara otomatis akan ditanggalkan dan fokus pada mengasah pengembangan kompetensi diri bersama peserta didik.

Kedekatan dan keterbukaan dengan peserta didik sangat diperlukan dalam proses pembelajaran di era modernitas ini. Akan tetapi guru profesional meskipun memiliki kedekatan dan keterbukan dengan peserta didik tetap harus autentik, artinya tidak berpura-pura dalam menilai kompetensi peserta didik atau memberikan feed back untuk mengembangkan potensi yang dimilikinya. Sikap wibawa selalu melekat dalam dirinya menegentaskan sikap infantil yang akan berpotensi menjadi "bulan-bulanan" seorang murid. Sebab itulah sikap wibawa seorang pendidik tumbuh dari rasa simpati peserta didik karena kebenaran kompetensi yang dimilikinya, bukan lahir dari rasa segan ataupun takut.

Antara guru tradisional dan guru profesional sama sekali tidak ada yang salah dalam hakikatnya sebagai guru. Keduanya sama-sama memiliki nilai mulia atas segala dedikasi dan jasanya dalam mengasah atau mengembangkan potensi murid. Akan tetapi jika dikomparasikan menggunakan pisau analisis secara mendalam, tentu terdapat sisi kelebihan dan kekurangannya masing-masing antara kedua model guru tersebut. Implikasi dari dua eksistensi model tersebut dalam implementasinya adalah mutu yang dihasilkan dan mutu individu pendidik.

Mutu pendidik dalam beberapa literatur disebutkan bahwa di antaranya adalah, pertama, komptetensi verbal dan kecerdasan dalam menuangkan ide-ide pikiran, mengeksplorasi serta berpikir secara diagnostik. Kedua, keterampilan tentang tata cara mengajar bidang studi yang diampunya, selain itu juga berkaitan dengan penguasan strategi dan teknik-teknik dalam mengajar untuk menstimulasi timbulnya higher order thinking skill. Ketiga, kompetensi menganalisis kebutuhan siswa, masalah yang dialami, serta style belajar dari peserta didik yang selanjutnya menjadi pemahaman holistik bagi seorang guru yang akan digunakan untuk merancang pembelajaran guna memperoleh nilai autetik dari seorang peserta didik. Keempat, skil beradaptasi yang harus dimiliki

15 Moh. Nawafil dan Junaidi, "Revitalisasi Paradigma Baru Dunia Pembelajaran yang Membebaskan”, Jurnal Pendidikan Islam Indonesia, Vol. 4, No. 2, (April: 2020), 218. 
oleh seorang guru guna menghayati segala sesuatu yang menjadi kebutuhan peserta didik serta mengaplikasikan kebijakan-kebijakan dalam dunia pendidikan. ${ }^{16}$

Terdapat berbagai macam model mutu, salah satunya ialah melalui perspektif model expert. Di mana model mutu yang satu ini menekankan pada penanaman nilai, perilaku, karakter dan profesionalitas yang dapat memberikan suatu pelayanan pendidikan. Sebagai profesionalitas, guru merupakan sosok yang paling dekat dan memiliki dominasi komunikatif kepada peserta didik serta kompleksitas pengetahuan yang dapat digunakan untuk mengambil keputusan-keputusan berkenaan aktivitas pembelajaran di sekolah. Sehingga keputusan-keputusan yang tepat sasaran dapat diwujudkan melalui analisis mendalam seorang guru serta hubungan personalitas yang begitu akrab dengan peserta didik. Suatu hal yang paling mendasar dari keberhasilan seorang guru profesional ialah sejauh mana mereka dapat memproduksi atau mempersiapkan anak didik yang berkualitas. Maka dari itu, mutu adalah nilai yang tidak bisa ditawar-tawar sekaligus high achievement.

Secara sempit, mutu sering dikaitkan dengan prestasi akademiki siswa, pengetahuan dan skill yang ditransformasikan antara guru dan murid, impact lulusan yang berkenaan dengan kebutuhan lapangan kerja terhadap lulusan. Akan tetapi dari sisi yang lebih luas, mutu pendidikan dapat dipandang melalui value, attitude, behaviour dalam diri siswa hingga menghasilkan suatu kerangka berpikir kritis dan bersikap terbuka terhadap hal-hal yang berbeda dengan dirinya, termasuk toleran, empati, ikhlas, tanggung jawab, dan sebagainya. ${ }^{17}$

Jika guru menjalankan tugas profesionalitas dengan sebenarnya, tentu mutu pendidikan yang berkenaan dengan karakter siswa tidak akan menjadi hayalan indah saja atau dongen di kertas ilmiah. Sebab pada akhirnya sosok kunci yang akan merealisasikan itu semua adalah seorang guru. Pada prinsipnya belajar tidak identik pada suatu kegiatan memindah alihkan pengetahuan dari satu otak (guru) ke otak yang lain (peserta didik) sebagaimana populer dengan

16 Linda Darling-Hammond, "Teacher Quality and Student Achievement: A Review of State Policy Evidence," Educational Policy Archives, Vol. 8, No. 1, (Januari: 2000), 47.

${ }^{17}$ Jejen Musfah, Redesain Pendidikan Guru: Teori, Kebijakan dan Praktik, (Jakarta: Kencana, 2015), 19. sebutan conventional theory of learning. Namun belajar merupakan suatu proses transformasi yang memproduksi nilai-nilai, karakter, sikap, guna menjadi bekal dalam menghadapi segala problematika kehidupan yang mengitarinya.

Melaui belajar yang tepat, maka peserta didik tidak hanya memperoleh pengetahuan akademis saja melainkan juga keperibadian yang luhur. Pribadi seseorang tidak dapat dibentuk begitu saja. Perlu upaya-upaya sistematis dan berkelanjutan dari seorang individu yang menjadi model karakter atau uswah. Individu tersebut adalah para guru di sekolah yang setiap harinya selalu menjalin interaksi dengan peserta didik. Pribadi yang dicontohkan guru setiap hari itulah yang nantinya sedikit banyak akan ditiru oleh murid. ${ }^{18}$ Berdasarkan hal tersebut, maka peran guru dalam membentuk kepribadian siswa sangatlah penting.

Karakter, nilai, sikap yang seharusnya menjadi sebuah parameter keberhasilan pendidikan, dalam hal ini guru, sungguh nyaris tidak didapat di media-media, bahkan wacanawacana publik kurang menyentuhnya. Bahkan bila mengikuti berita-berita yang telah diekspos beberapa media masa baik cetak maupun online mayoritas tentang kenakalan remaja, kekerasan, tawuran, ugal-ugalan, bahkan tindakan cabul seorang guru terhadap siswinya yang menjadi head line news. Tentu ini sudah menjadi pukulan telak terhadap dunia pendidikan yang harus seitap waktu berbenah menjadi lebih baik. Walaupun perilaku-perilaku menyimpang terasebut dilakukan oleh para oknum, yang tidak semuanya individu dalam dunia pendidikan melakukan hal tersebut. akan tetapi mengingatkan tujuan pendidikan yang fokus utamanya adalah penghambaan diri kepada Allah secara totalitas merupakan hal yang penting dilakukan. Supaya kualitas pembelajaran tidak hanya berorientasi pada sisi kognitif saja, melainkan kepribadian yang mengandung karakter-karakter luhur.

Jika ditelisik dari makna katanya, karakter berasal dari bahasa Yunani yani kharaseein. Dalam epistimologi Yunani, kharaseein adalah alat yang digunakan untuk memuat gravir atau membuat suatu guratan. Selain itu, kharaseein juga diartikan sebagai permata berharga, tanda atau stempel atau

18 Moh. Nawafil dan Hafifuddin Nur, "Pendidikan Indigenous Ala Pesantren untuk Memperkokoh Karakter Generasi Milenial", Edupedia: Jurnal Studi Pendidikan dan Pedagogi Islam, Vol. 5, No. 1, (Juli: 2020), 21. 
ciri-ciri yang dapat membedakan. ${ }^{19}$ Sederhanya adalah tanda-tanda yang dapat membedakan seseorang dari yang lain atau menonjolkan ciri-ciri seorang disebut sebagai karakter. Dibentuknya karakter yang luhur bertujuan untuk membentuk seseorang yang unggul dan menegaskan eksistensi dirinya. Sebab pada esensinya, karakter adalah kepribadian seseorang yang memiliki kualitas mental dan moral, kualitas diri, basis berpikir yang bisa membedakan dengan lainnya.

Asaz-asaz pendidikan yang terdiri dari belajar untuk memahami, belajar untuk aksi, belajar untuk masa depan, dan belajar untuk hidup sebagai makhluk sosial masih belum semuanya terserap dengan sempurna. Kalaupun ada yang banyak terserap, mungkin hanya sebatas learning to know dan learning to do. Sedangkan learning to live together dirasa kurang tercerna dalam kepribadian peserta didik. Hal ini diindakasikan dengan maraknya tawuran antar pelajar yang mana tidak mencermikan sekali dari ciri-ciri learning to live together di mana asas-asasnya adalah untuk hidup bersama, saling rukun dan hormat menghormati antar sesama makhluk.

Lalu bagaimana cara agar karakter, sikap, nilai bisa tertanam pada diri peserta didik melalui aktivitas pembelajaran? Maka terdapat dua pendekatan dalam pendidikan karakter, yang pertama adalah pendekatan tradisional dan kedua adalah komprehensif. Tentu kedua pendekatan pendidikan karakter ini memiliki perbedaan yang mendasar. Pendidikan karakter melalui pendekatan tradisional sering mencerminkan pada aspek modelling, habituation, instruction, dan reward. Sedangkan pendidikan karakter yang melalui pendekatan integratif atau terpadu dapat dilihat dari tiga sisi yakni, pertama adalah thingking, merupakan aktivitas kognitif peserta didik untuk beripikir tentang apa saja yang telah dipelajari. Kedua, adalah afeksi, yakni sikap atau sebuah rasa peserta didik dalam menghayati segala materi pelajaran yang sudah dipikirkan pada taraf kognisi kemudian diapresiasikan menjadi moralitas dalam diri peserta didik. Ketiga, adalah paksis, yaitu upaya pendidik dalam membawa peserta didik ke jenjang yang lebih real, di mana peserta didik tidak hanya sebatas mendiskusikan materi

${ }^{19}$ Jejen Musfah, Redesain Pendidikan Guru: Teori, Kebijakan dan Praktik, (Jakarta: Kencana, 2015), 25.

${ }^{20}$ Djuwairiyah dan Moh. Nawafil, "Urgensi Pengelolaan Kelas; Suatu Analisis Filosofis dan Pemahaman Dasar Bagi Kalangan Pendidik di Pesantren", Edupedia: Jurnal Studi pembelajaran namun lebih pada pengamalan pada realitas kehidupan. ${ }^{20}$

Terdapat lima prinsip dalam pendidikan karakter melalui pendekatan terpadu. Pertama adalah berkenaan dengan subject of matter. Seharusnya mata pelajaran pendidikan karaker bukan sebagai mata pelajaran tunggal, akan tetapi sebuah materi yang terintegerasi dengan materi lain. Kedua, pendidikan karakter merupakan sebuah praksis yang mana tujuan utamanya adalah bersifat pengamalan-pengamalan nilai-nilai luhur. Jadi materi yang didapat oleh siswa tidak menjadi buah pengetahuan kognitif saja, akan tetapi dapat bermakna dengan wujud aksi. Ketiga, pendidikan karakter sepatutnya ditanamkan dalam lingkungan sekolah. Sehingga para siswa dan guru sama-sama memiliki komitmen untuk mengamalkan nilai atau karakter yang hendak ditanamkan dalam proses pembelajaran. Keempat, pendidikan karakter sejatinya harus tercermin dalam satu bagian visi, misi dan kebijakan sekolah. Lantas tidak hanya menjadi verbalisme murni belaka, akan tetapi ada sebuah ketetapan target yang harus dicapai. Kelima, pendidikan karakter yang begitu kompleks dan membutuhkan porsi waktu yang tidak sedikit, sebab itulah pendidikan karakter seyogyanya diajarkan oleh pendidik yang mempunyai jiwajiwa pemberani untuk melakukan hal-hal inovatif.

Adapun metode pembelajaran pendidikan karakter dapat berupa penanaman kebajikan dan nilai-nilai dasar. Cerita-cerita yang penuh dengan kandungan nilai dan moral. Uswah dan moral yang menjadi basis kehidupan. Menampilkan contohcontoh moral dari religiusitas, histori, kesustraan, dan mensosialisasikan sifat orang-orang yang memiliki nilai baik. Dalam aktivitasnya, guru akan selalu menemukan tantangan. Tantangan seorang guru merupakan cara menakar suatu metode pembelajaran berdasarkan kebutuhan peserta didik supaya tujuan pembelajaran dapat tercapai dengan baik dan mencapai keberhasilan belajar. ${ }^{21}$ Namun jika tantangan tersebut dapat dilalui dengan baik, tentu kompetensi guru akan semakin mempuni.

Pendidikan dan Pedagogi Islam, Vol. 5, No. 2, (Januari: 2021), 32.

${ }^{21}$ H. M. Zainuddin, "Implementasi Pembentukan Karakter Bersahabat Melalui Model Pembelajaran Group Investigation", Mimbar, Vol. 29, No. 1, (Juni: 2013), 70. 


\section{Penghayatan Qolb, Nafs dan Aql bagi Pendidik dalam Membendung Perilaku Menyimpang Siswa}

Sebagai pendidik yang bermutu sebagaimana yang telah dijelaskan di atas, maka kompetensi dasar dalam diri pendidik sejatinya harus tertanam dengan baik. Kompetensi tersebut salah satunya adalah kompetensi pedagogik ataupun kompetensi profesionalitas. Di mana kompetensi ini mensyaratkan atas kemampuan guru dalam memahami kepribadian peserta didik juga atas materi yang harus dipahami dengan baik. Tentu dalam membentuk sikap peserta didik yang luhur tidaklah segampang wacana-wacana yang tergores rapi di kertas-kertas koran dan akademik. Perlu adanya upaya yang memeras tenaga berbagai pihak, khususnya bagi para guru yang memiliki intensitas porsi berinteraksi yang lumayan banyak kepada peserta didik.

Adapun materi-materi pembelajaran yang seyogyanya dimiliki oleh guru ialah berkenaan dengan qolb, nafs, dan aql. Sebab materi ini merupakan materi yang secara khusus dapat memahami kepribadian luhur sejati sehingga dapat ditanamkan dalam diri peserta didik. Melalui pemahaman paripurna terhadap qolb, nafs, dan aql diharapkan bisa menjadi jati diri pendidik yang luhur dan menerbakan nilai-nilai kebaikan. Sehingga nantinya bukan hanya sebatas transformasi kognitif saja, akan tetapi lebih pada uswah yang benar-benar ideal untuk ditiru oleh peserta didik.

Dari segi istilah, kata nafs berasal dari bahasa Arab yang berarti jiwa atau soul. ${ }^{22}$ Namun hal itu merupakan pengertian secara umum saja, yang mana jiwa juga memiliki pengertian universal. Jiwa diartikan sebagai sebuah rasa semangat, nyawa, dan tabiat. Dalam beberapa literlek filsafat dan agama, jiwa tidak didefinisikan sebagai sifat jasmaniah, melainkan sebuah esensi immaterial. Terdapat padanan kata yang serupa dengan nafs dalam bahasa Arab, di antaranya ialah esensi makhluk, ruh, aliran darah, atau sesuatu yang lemut. ${ }^{23}$ Jadi, istilah jiwa yang berkenaan pada sifat-sifat internal batiniyah sudah lumayan kuat eksistensinya. Akan tetapi pada perkembangannya, istilah jiwa begeser pada aspek fisiologis individu.

22 Ahmad Warson Munawwir, Al Munawwir: Kamus ArabIndonesia, (Surabaya: Pustaka Progresif, 1997), 1087.

23 Ahmad Arisatul Choliq, "Relasi Akal dan Hati Menurut Al-Ghazali”, Journal Kalimah, Vol. 3, No. 2, (September: 2015), 291.
Alquran mendefinisikan kata nafs pada empat aspek. Pertama adalah nafsu. Kedua adalah nafas. Ketiga, jiwa. Adapun yang keempat ialah diri. Hal ini tertuang dalam firman Allah SWT yang berbunyi kullu nafsin draikatul maut. Di mana setiap makhluk yang bernyawa pasti akan menemukan ajalnya. Aspek yang mengalami kematian tersebut masih menimbulkan perdebatan-perdebatan serius di kalangan para ulama.

Sayyid Qutb misalnya, beliau menjelaskan bahwa adanya kematian ditandai dengan lenyapnya nafs (jiwa). Namun di sisi lain, kematian tidak identik dengan lenyapnya nafs atau jiwa, sebab aspek yang musnah ialah aspek lahiriah dalam hal ini tubuh, sedangkan ruh atau jiwa tidak mengalami kematian. Ungkapan terakhir ini ialah statement populer Ar-Razi. Sehingga nafs yang disebut itu ialah nafs dalam makna nyawa. Sebab adanya nyawa berimplikasi terhadap adanya albayat. $^{24}$

Menurut Al-Ghazali, jiwa adalah sebuah tatanan esensial yang memliki sifat independent, subjek yang mengetahui dan bersifat permanen. Artinya, jiwa adalah suatu identitas hakiki yang sifatnya berdiri sendiri tanpa ketergantungan dengan tidak bertempat. Hal ini tentu terdapat perbedaan mendasar dengan fisik atau fungsi fisik manusia yang mana intisari seorang individu berada pada substansi immaterialnya. Sebab sesuatu yang mempunyai tempat disebut sebagai fisik dan yang tidak dapat berdiri sendiri merupakan fungsi fisik. Oleh karena itu, pada statement yang berkualitas, Al-Ghazali mengungkapkan bahwa fisik tidak ubahnya sebagai pernak-pernik lahiriah saja yang menghiasi jiwa, sebab jika anggota fisik sudah mati, baik dzahir wa batinan, maka tidak demikian halnya dengan jiwa. Sejatinya jiwa tidak ikut rapuh, punah, dan musnah bersama aspek batiniyah. ${ }^{25}$

Perbuatan seseorang banyak dipengaruhi oleh keadaan jiwanya. Jika jiwa seseorang baik, maka perilakunya juga akan baik. Begitu pun sebaliknya. Walaupun beberapa literatur banyak mengurai tentang eksistensi dari sebuah potensi kebaikan yang ada dalam diri manusia lebih dominan ketimbang potensi keburukan yang

${ }^{24}$ Baharuddin, Paradigma Psikologi Islami Studi tentang Elemen Psikologi dari Alquran, (Yogyakarta: Pustaka Pelajar, 2007), 91 92.

25 Ahmad Arisatul Choliq, "Relasi Akal dan Hati Menurut Al-Ghazali”, Journal Kalimah, Vol. 3, No. 2, (September: 2015), 292-293. 
berada dalam diri individu. Sejalan dengan tafsir yang disampaikan oleh M. Quraish Shihab bahwa jiwa manusia lebih dekat pada melakukan hal-hal yang positif dari pada melakukan hal-hal yang negatif. Hal ini merupakan buah dari tafsir sebuah ayat Al-Baqarah: 286, Laba Ma Kasabat wa Alaiha Maktatsbat. ${ }^{26}$ Maka dari itulah manusia seharusnya selalu menjaga kesucian jiwanya melalui tindakantindakan positif.

Untuk menjaga kesucian jiwa maka terdapat peran penting sebuah qolb dan aql. sehingga bisa menggerakkan nafs pada tingkatan nafsu mutmainnah. Nafsu mutmainnah adalah nafsu yang berperan sebagai pendorong manusia terhadap hal-hal yang positif dengan bingkai ketenangan jiwa. Jika nafsu manusia sudah pada tataran nafsu melakukan hal-hal yang baik, maka dengan sendirinya nafsu amarah bissu' akan terlampaui. Lebih lanjut, dijelaskan bahwa nafsu amarah ialah nafsu yang menstimulasi individu untuk melakukan pemuasan kebutuhan badannya saja. Nafsu ini pada biasanya mendorong manusia pada keinginan-keinginan rendah yang mana nantinya bisa menyebabkan seorang insan terus menerus bertindak negatif.

Perilaku-perilaku negatif yang terjadi pada lingkup dunia pendidikan ialah tawuran pelajar, radikalisme agama, dan sebagainya. Untuk mengentaskan hal tersebut, penting kiranya eksistensi hati dan akal untuk mendorong jiwa menjadi jiwa yang tulus dengan selalu berorientasi pada hal-hal yang baik. Hati dan akal dapat menjadi ciri khas dimesi nafs manusia. Di samping itu juga berperan sebagai penentu kadar dan value kejiwaan manusia. ${ }^{27}$

Dalam Kamus Besar Bahasa Indonesia, hati memiliki makna sebagai suatu aspek isi perut bagian atas, memiliki warna merah kehitamhitaman yang berfungsi sebagai pengambil sarisari makanan di dalam darah dan memproduksi empedu. ${ }^{28} \mathrm{Al}$-Ghazali memberikan dua definisi tentang hati. Pengertian qolb yang pertama adalah segumpal daging yang tertancap dalam tubuh sebelah kiri dari posisi dada makhluk, yang secara spesifik berada pada rongga penuh gumpalan darah hitam. Qolb ini diberikan oleh Allah SWT kepada makhluk-Nya baik itu hewan ataupun

26 Jalaluddin Muhammad bin Ahmad bin Muhammad alMahalli dan Jaluddin Abdurrahman bin Abu Bakr as-Suyuthi, Tafsir al-Jalalain, (Jakarta: Darul Kutub al-Islamiyah, 2011), 92.

27 Baharuddin, Paradigma Psikologi Islami Studi tentang Elemen Psikologi dari Al Qur'an, (Yogyakarta: Pustaka Pelajar, 2007), 161-163. manusia. Sehingga sumber ruh manusia dan segala tempat rahasia-rahasia Allah ialah terletak pada qolb itu sendiri.

Definisi qolb yang kedua adalah sesuatu yang dianugerahkan oleh Allah kepada manusia hingga menjadi sebuah esensi maknawi yang dapat digunakan untuk membedakan mana yang alim dan mana yang arif. Melalui qolb inilah yang berperan sebagai penunjuk dan penentu sesuatu hal yang hendak dilakukan oleh manusia, baik itu hal-hal buruk ataupun hal-hal positif. Berangkat dari qolb pula, derajat manusia bisa lebih tinggi dari pada malaikat. Sebaliknya, derajat manusia juga bisa lebih rendah dari binatang jika hatinya dipenuhi oleh kotoran-kotoran hati.

Adapun obat bagi hati yang gersang ialah melalui membaca Alquran dan memahami maknanya, perbanyak drikir di waktu malam, harus mengurangi makan, sholat malam, berkawan dengan orang-orang yang sholeh. Hal tersebut sebagaimana tertuang dalam syair-syair yang sering digunakan dalam dzikir sebelum shalat di kalangan masyarakat ablusunnah waljamaah.

Dari asal katanya, kata aql berasal dari bahasa Arab yang berarti mengikat atau menawan. ${ }^{29}$ Jadi, akal juga bermakna mengikat atau mengendalikan sebuah pikiran, jiwa, perilaku dan perkataan. Al-Ghazali membagi akal mejadi dua bagian. Pertama ialah akal teoritis. Akal teorits memiliki fungsi menyempurnakan substansinya. Adapun substansinya itu ialah bersifat immater dan abstrak. Terdapat tingkatantingkatan akal dari akal hayuulani sampai akal mustafad.

Akal hayuulani ialah posisi akal yang masih berupa potensi. Akal bil malakah ialah akal yang bersifat properti dan biasanya sering digunakan untuk merenung. Selain akal hayuulani dan akal bil malakah, terdapat juga akal bil fi'li yakni akal yang sudah berfungsi merespon hal-hal realitas berupa tindakan atau aksi. Selanjutnya ialah akal tertinggi, yakni akal mustafad, yakni sebuah akal yang selamanya aktual. Adapun akal praktis adalah kekuatan yang bertanggung jawab mengorganisasikan badan yang terintegerasi dengan hasrat dengan menstimulasi manusia

\footnotetext{
${ }_{28}$ Tim Pandom Media, Kamus Besar Bahasa Indonesiia: Edisi Baru, (Jakarta: Pandom Media Nusantara, 2014), 307. 29 Ahmad Warson Munawwir, Al Munawwir: Kamus ArabIndonesia, (Surabaya: Pustaka Progresif, 1997), 957.
} 
melakukan aneka perilaku parsial. Seperti, segan, malu, tertawa, menangis dan sebagainya. Fungsi akal praktis ialah untuk mengontrol hawu nafsu sehingga dapat mengantarkan manusia ke tingkah laku yang lebih sempurna.

Penghayatan terhadap nafs, qolb dan aql ini oleh pendidik, diharapkan dapat menjadi sebuah ilmu pengetahuan hakiki yang menghantarkan pada suri tauladan yang baik bagi peserta didik. Sebab sebagaimana penjelasan di atas peran mereparasi jiwa, hati dan akal bisa dijadikan sebagai wasilah pendidik guna mencegah perilakuperilaku menyimpang peserta didik. Mengandalkan kecerdasan intelektual saja tidak cukup, perlu adanya hati yang bersih sehingga menghasilkan jiwa yang tenang. Selanjutnya berdampak pada perilaku-perilaku luhur yang terermin dari individu peserta didik.

\section{SIMPULAN}

Perlu adanya usaha efektif untuk menyelesaikan berbagai persoalan dalam dunia pendidikan, lebih-lebih permasalahan kenakalan remaja dan radikalisme agama. Salah satu peran penting yang potensial dalam menangkal hal terebut ialah kiprah dari seorang pendidik. Sebab pendidik adalah aktor utama yang memiliki kuota komunikasi lebih kepada peserta didik. Peran guru sebagai subjek kunci yang memiliki porsi waktu berkomunikasi lebih dominan bersama peserta didik menjadi sangat vital eksistensinya guna menyelesaikan problematika perilaku menyimpang. Oleh karena itu sangat dibutuhkan kiprah seorang pendidik yang bermutu tinggi. Mutu seorang pendidik dalam beberapa literatur disebutkan bahwa kompetensi menganalisis kebutuhan siswa, masalah yang dialami, serta style belajar dari peserta didik yang selanjutnya menjadi pemahaman holistik bagi seorang guru yang akan digunakan untuk merancang pembelajaran guna memperoleh nilai autetik dari seorang peserta didik. Penghayatan terhadap nafs, qolb dan aqloleh pendidik, diharapkan dapat menjadi sebuah ilmu pengetahuan hakiki yang menghantarkan pada suri tauladan yang baik bagi peserta didik. Sebab sebagaimana penjelasan di atas peran mereparasi jiwa, hati dan akal bisa dijadikan sebagai wasilah pendidik guna mencegah perilaku-perilaku menyimpang peserta didik

\section{DAFTAR RUJUKAN}

al-Mahalli, Jalaluddin Muhammad bin Ahmad bin Muhammad dan Jaluddin Abdurrahman bin Abu Bakr as-Suyuthi. Tafsir al--Jalalain. Jakarta: Darul Kutub al-Islamiyah, 2011.

Aziz, Abd. Filsafat Pendidikan Islam: Sebuab Gagasan Membangun Pendidikan Islam. Yogyakarta: Teras, 2009.

Baharuddin. Paradigma Psikologi Islami Studi tentang Elemen Psikologi dari Alquran. Yogyakarta: Pustaka Pelajar, 2007.

Choliq, Ahmad Arisatul. "Relasi Akal dan Hati Menurut Al-Ghazali”, Journal Kalimah, Vol. 3, No. 2, (September: 2015).

Darling-Hammond, Linda. "Teacher Quality and Student Achievement: A Review of State Policy Evidence," Educational Policy Archives, Vol. 8, No. 1, (Januari: 2000).

Dewantara, Ki Hajar. Bagian Pertama: Pendidikan. Yogyakarta, Yayasan Persatuan Taman Siswa, 2011.

Djuwairiyah dan Moh. Nawafil, "Urgensi Pengelolaan Kelas; Suatu Analisis Filosofis dan Pemahaman Dasar Bagi Kalangan Pendidik di Pesantren", Edupedia: Jurnal Studi Pendidikan dan Pedagogi Islam, Vol. 5, No. 2, (Januari: 2021).

Habziz, Khairuddin. Kaidah Ushul Fiqh. Situbondo: Tanwirul Afkar, 2019.

Jalaluddin dan Abdullah Idi. Filsafat Pendidikan: Manusia, Filsafat dan Pendidikan. Depok: Raja Grafindo Persada, 2016.

Kartono, Kartini. Kenakalan Remaja. Jakarta: Raja Grafindo Persada, 2006.

Munawwir, Ahmad Warson. Al Munawnir: Kamus Arab-Indonesia. Surabaya: Pustaka Progresif, 1997.

Muqoyyidin, Andik Wahyun. "Membangun Kesadaran Inklusif-Multikultural untuk Deradikalisasi Pendidikan Islam", Jurnal Pendidikan Islam, Vol. 2, No. 1, (Juni: 2013).

Musfah, Jejen. Redesain Pendidikan Guru: Teori, Kebijakan dan Praktik. Jakarta: Kencana, 2015.

Nawafil, Moh. dan Hafifuddin Nur, "Pendidikan Indigenous Ala Pesantren untuk Memperkokoh Karakter Generasi Milenial", Edupedia: Jurnal Studi Pendidikan dan Pedagogi Islam, Vol. 5, No. 1, (Juli: 2020).

Nawafil, Moh. dan Junaidi. "Revitalisasi Paradigma Baru Dunia Pembelajaran yang Membebaskan", Jurnal Pendidikan Islam Indonesia, Vol. 4, No. 2, (April: 2020).

Rokhmad, Abu. "Radikalisme Islam dan Upaya Deradikalisasi Paham Radikal," Walisongo, Vol. 20, No. 1, (Mei: 2012). 
Smith, William A. Conscientizacao: Tujuan Pendidikan Paulo Freire. Yogyakarta: Pustaka Pelajar, 2008.

Syafi'i, Sufyan "Urgensitas Sanad sebagai Modal Sosial Pesantren dalam Deradikalisasi Islam", The International Journal of Pegon Islam Nusantara Civilixation, Vol. 3, No. 2, (Maret: 2020).

Syarbini, Amirullah. Pendidikan Karakter Berbasis Keluarga: Studi Tentang Model Pendidikan Karakter dalam Keluarga Perspektif Islam. Yogyakarta: Ar-Ruzz Media, 2016.

Zainuddin, H. M., "Implementasi Pembentukan Karakter Bersahabat Melalui Model Pembelajaran Group Investigation", Mimbar, Vol. 29, No. 1, (Juni: 2013).

Tim Pandom Media, Kamus Besar Bahasa Indonesiia: Edisi Baru. Jakarta: Pandom Media Nusantara, 2014. 